\title{
Cycles and Bank Credit Allocation in EU Countries: An Empirical Study
}

\author{
Giscard Assoumou Ella ${ }^{1} \&$ Marie-Sophie Gauvin ${ }^{2}$ \\ ${ }^{1}$ CIREGED, Université Omar Bongo, Gabon \\ ${ }^{2}$ IREA, LEAD, Université de Bretagne Sud, Vannes, France \\ Correspondence: Maie-Sophie Gauvin, Université de Bretagne Sud, Vannes, France. E-mail: \\ marie-sophie.gauvin@univ-bs.fr
}

Received: April 1, 2015

Accepted: April 18, 2015

Online Published: May 25, 2015

doi:10.5539/ijef.v7n6p31

URL: http://dx.doi.org/10.5539/ijef.v7n6p31

\begin{abstract}
The increase in the amount of commercial papers and the real estate price boom before the 2007-2008 crisis witness a preference for speculative assets by banks. In contrast, after the crisis, banks tended to opt for safe assets, and especially during the Eurozone debt crisis with a sharp increase in deposit facilities from July 2011 to December 2011. This credit allocation can be at the detriment of productive assets; therefore, it can affect the real economy. This paper analyzes empirically the credit allocation of monetary and financial institutions in countries of the European Union over the period 1997-2013. Our results show that risk aversion stands as a main explanation of balance sheet movements. If risk aversion is largely influenced by monetary policy before the crisis, risk perception is uncorrelated to monetary policy afterwards.
\end{abstract}

Keywords: monetary policy, Eurozone, cycles, risk aversion, banking system

\section{Introduction}

The supply of bank credit over business cycle is largely studied with a significant increase in lending in the upward phase and a "credit crunch" after a crisis. These movements concerning the credit activity participate to the amplification of changes in economic activity, which means that the bank loan supply is procyclical. Nevertheless, there are few studies that take into account credit allocation (Berger \& Udell, 2004). This paper proposes to analyze credit allocation between productive assets versus speculative ones and tries to consider the causes of this allocation over the cycle. We consider that, in regard to granting loan, bank behaviors depend on risk aversion, which varies over the cycle. Moreover, risk aversion is differently affected in the upward and the downward phases. According to the risk taking channel, monetary policy impacts risk perception and encourages risk taking by banks when interest rates are low. If this channel is effective before the crisis banks tend to flight to liquidity just after the crisis even if interest rates are maintained low because of a high risk aversion. The aim of our empirical study is to assess the impact of both monetary policy and risk aversion on credit allocation over the cycle.

In the following section, determinants of bank choices are identified. Before putting forward monetary policy and risk aversion in the credit allocation process, we define the concept of risk aversion in order to show that it is countercyclical. Section III describes data and variables. Section IV presents the empirical model. Finally, results and conclusions are presented in the last section.

\section{Survey}

Bank choices depend inter alia on bank risk aversion. In this paper, we consider that, even if risk aversion is an intrinsic element of the investor nature (Gai \& Vause, 2004), it also depends on the level of uncertainty, so it can vary over the business cycle (it refers to the notion of "risk appetite"). Consistent with theoretical intuition, Smith and Whitelaw (2009), in an empirical study over the period 1952-2005, find, thanks to a time-varying risk aversion, that the price of risk varies counter-cyclically and increases substantially over the course of economic contractions. In the upward phase of the cycle, risks can be underestimated (Note 1). Indeed, a climate of confidence favors careless behaviors and excess of credit (Thornton, 1803). On the contrary, in the downward phase, banks revise their expectations and cause a reversal of risk aversion. The market refers to majority opinion and the rise in risk aversion is accentuated by a collateral increase. In summary, risk sensitivity is 
exacerbated in the downward phase.

Bank behaviors relative to risk aversion can be also influenced by the action of other agents. Recent studies highlight the role of monetary policy in the risk taking of banks before the crisis. The risk taking channel describes «the impact of changes in policy rates on either risk perceptions or risk-tolerance and hence on the degree of risk in the portfolios, on the pricing of assets, and on the price and non-price terms of the extension of funding » (Borio \& Zhu, 2012). Banks consider market perception (Gambacorta \& Marques-Ibanez, 2011) and so react in function of the Central bank action. A decrease in interest rate by the Central bank can favor an excessive risk taking by banks because of the modification of risk perception. Low interest rates boost the net asset value and therefore increases the demand of investment and decreases the default probability, which allows an underestimation of risks (Gambacorta, 2009). In addition, low interest rates entail low expected yields, so encourage banks to choose more profitable assets, which are also more risky (Cardone-Riportella, Samaniego-Medina, \& Trujillo-Ponce, 2010) (see "search for yield" in Rajan, 2006). The risk taking channel is confirmed in several empirical studies on different samples: for American (Altunbas, Gambacorta, \& Marqués-Ibáñez, 2010), European (Delis \& Kouretas, 2011; Maddaloni \& Peydró, 2011), Bolivian (Ioannidou, Ongena, \& Peydró-Alcalde, 2008), and Spanish banks (Jimenez et al., 2014).

On the contrary, after a crisis, we used to witness a credit rationing amplified by information asymmetries. The risk becomes a central element for banks, that face to liquidity risk and counterpart risk. Banks fear difficulties about refinancing in the future (Caballero \& Krishnamurthy, 2008; Allen, Carletti, \& Gale, 2009), and are not confident about the ability of other banks to pay their debts, especially in a context of strong information asymmetries (Freixas \& Jorge, 2008). After the 2007-2008 crisis, the monetary policy tend to reduce the credit rationing and avoid some bank failures by using unconventional methods. In addition to large cuts in official interest rates, Central banks, including the ECB, provided massive liquidity and purchased a wide range of assets (Bernanke, Reinhart, \& Sack, 2004). Very low official interest rates are aimed at reducing the refinancing cost of banks and the all instruments are intended to reduce risk aversion. Using such measures witness the importance of risk aversion on bank decision and the inefficiency of low interest rates in bad times to encourage credit and especially productive credit. Some studies highlighted the impact of monetary policy on spreads after the 2007-2008 crisis. (Andritzky et al., 2009). According to Wu (2008), asset purchases and liquidity provisions seem to calm interbank strains, but the ECB interest rates policy tend to accentuate risk aversion, which could be explained by the prevalence of the liquidity and counterpart risks, that were dominant factors in the different stages of the 2007-2008 crisis, especially in the Eurozone (Angelini, Nobili, \& Picillo, 2011).

To sum up, keeping low interest rates after the 2007-2008 crisis did not calm market tensions. So bank decisions concerning credit allocation are more guided by bank risk aversion than traditional monetary policy (which is justifying the use of unconventional monetary measures). Here, in the downward phase, high risk aversion leads to a credit rationing to the benefit of a "flight to quality" or "flight to liquidity" as evidenced, for example, by the preference for the TBill in United States, whose 3 month return reaches a zero level in the last quarter of 2008 (Banque de France, 2012). Concerning the Eurozone, flight to quality has another form since public assets are not anymore considered as safe in a special context of sovereign debt crisis at the end of 2010. If some Bonds, as German, continue to represent a safe haven, other Bonds, which have bad performance (Greece, Ireland), are neglected. The flight to quality in Eurozone actually plays an important role but occurs in the form of a rise in deposit facilities (Gilles et al., 2013) (see Figure 1).

Briefly, bank balance sheets are highly procyclical and reveal a preference for speculative assets in the upward phase and a flight to quality in the downward phase. These movements occur at the expense of productive assets, and depend on bank choices, which depend themselves on their risk perception, that is influenced differently over the cycle. On the one hand, risk appetite of banks is largely influenced by the monetary policy in the upward phase; on the other hand, risk perception is so sensitive to liquidity and counterpart risks in the downward phase that changes in interest rates do not affect behaviors in the downward phase.

This paper analyzes determinants of credit allocation by banks in European countries over the cycle. We will see that risk aversion is a large component of explanation. In the upward phase, risk aversion is largely influenced by the monetary policy and in the downward phase, risk perception is uncorrelated to monetary policy. 


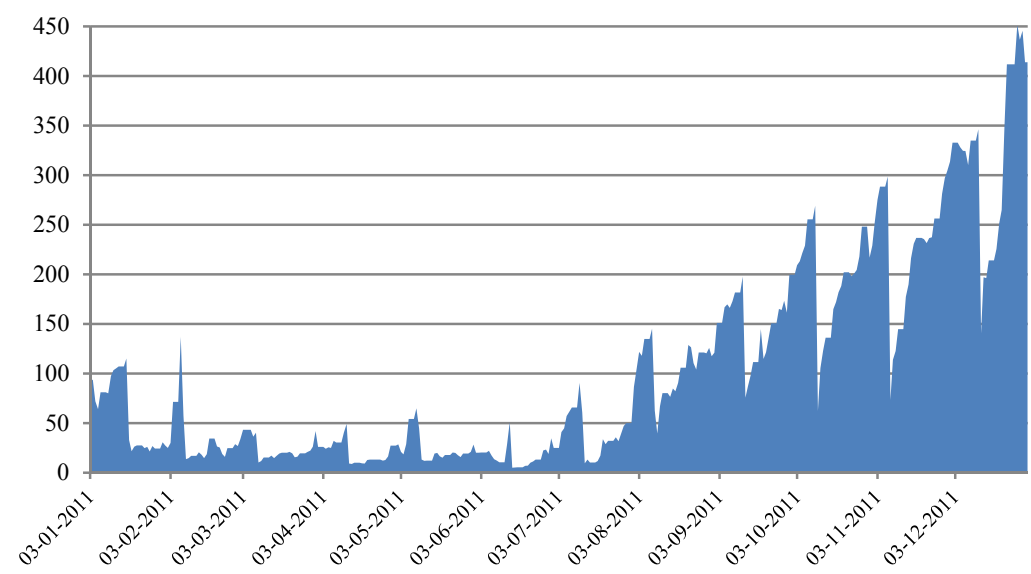

Figure 1. Deposit facilities in euro-zone, end of 2011 (ECB, Mds d'€)

\section{Data and Variables}

We choose to study aggregated balance sheets of Monetary Financial Institutions (MFI) in some European countries (Note 2), excluding the ECB, that is to say resident credit institutions and other resident financial institutions which receive deposits from other entities, grant credits and make investments in securities. According to Brissimis and Delis (2010), choosing European countries is appropriate to study the relationship between monetary policy and bank risk taking because "ECB pursues, more clearly than the Federal Reserve, the objective of price stability above all potential other objectives". Consequently, monetary policy is not used to influence performance of the banking sector. So, our study can effectively capture the impact of monetary policy on bank choices over the cycle. To consider the latter, our period of study starts in September 1997 and ends in December 2013 (with a break in August 2008, date of Lehman Brothers bankrupt).

The aim of the model is to analyze credit allocation over the cycle and its determinants. Most previous studies have modelled credit to private sector as a whole (Calza, Manrique, \& Sousa, 2006; Rossi \& Gambacorta, 2007). Our study differentiates assets according to their finality (productive asset versus speculative ones) and not according to their maturities (which could inform about the risk of run when the maturity structure of assets and liability is too much divergent). Consequently, we try to explain the evolution of three assets over the cycle: a "speculative asset", a "safe asset" and a "productive one". The difference between the speculative and the productive assets is that the first does not have any linkage with real activity and the second directly finances a productive project.

For the three dependent variables, data are provided by the ECB Statistical Data Warehouse in the category "MFI Balance Sheet Items Statistics". Data are collected monthly. First, concerning the speculative asset, we consider debt securities other than shares to MFI (heareafter referenced as sec). They are issued by EU countries residents and euro denominated issues issued by the Rest of the World and securities issued by residents of non-euro area EU Member States. We consider this asset as a speculative one since it does not finance productive project.

Second, concerning the safe asset, given the particularity of European countries in the context of sovereign debt crisis in 2010, government bonds are not a good proxy of safe assets (since our sample includes Greece, Ireland and Portugal that defaulted). We prefer to consider deposit facilities by MFI with the ECB. MFI can access the Eurosystem's standing facilities with an overnight maturity. Analyzing deposit facility (referenced as deposit) allows us to capture the flight to quality in the downward phase since banks prefer to choose safety and liquidity rather than profitability. We can note that considering this type of assets reflects also partially non-standard monetary policy measures. Indeed, “on 10 May 2010, the Central banks of the Eurosystem started purchasing securities in the context of the Securities Markets Programme (SMP), with a view to addressing the severe tensions in certain market segments which have been hampering the monetary policy transmission mechanism" (ECB).

Thirdly, our productive asset is approached by loans to Non Financial Corporations (named $n f c$ ). Using this variable permits to capture the effect on real activity since, in the European countries, bank lending is one of the major sources of financing for non financial corporations (Kok Sorensen, Marques-Ibanez, \& Rossi, 2012).

All the data are provided by the ECB, except the VSTOXX given by the Data Center of Stoxx, GDP from World 
Bank and inflation from Eurostat. First, we want to know how monetary policy impacts credit allocation over the cycle. We use the ECB policy rate (Note 3) (ecbir) as a measure of traditional monetary policy in the EU countries. The second determinant we want to assess over the cycle is risk aversion, which is approached by the Eurostoxx 50 Volatility (VSTOXX). VSTOXX is the European VIX (Note 4), it measures the volatility of near term options on the Eurostoxx 50 index by analyzing the square root of the implied variance across all options of a given time to expiration. In the three equations, we control for the economic conditions by real GDP growth for European Union countries (denoted by GDP) and inflation (inf) (Note 5). Another control variable is the Dow Jones Euro Stoxx 50 Price Index, denoted Index, which takes into account the market capitalization-weighted stock index of 50 large European companies operating within Eurozone nations. As it is reconstituted annually and the weightings are updated once per quarter, using this index allows us to consider changes in market capitalizations and so cyclical variations. Another variable that considers the cycle is the monetary aggregate M3 (Note 6). Lastly, we use as control variable the Composite Indicator of Systemic Stress (CISS), which is a new indicator of financial stability in several markets (Bonds, equities, foreign exchange and money markets) in Euro area (see Hollo, Kremer, \& Lo Duca, 2012 for the construction of this indicator).

\section{The Empirical Model}

We want to know how monetary policy and risk aversion impact credit allocation over the cycle. Concerning the choice of the adapted empirical model ("panel data" or "pooling"), we firstly verify if there are individual effects in the data, and then we formalize them in fixed and random effects.

In the Error Component Models, specific individual and temporal effects are random. In this study, we use the simplified model where it is supposed that the perturbation of the model is only composed by $\alpha_{i}$, a specific individual effect and $\mathrm{e}_{\mathrm{i}, \mathrm{t}}$, a random perturbation. According to Pirotte (2011), this presentation is usually used in the literature of applied economy with the panel data, because the available statistics frequently concern the individual dimension. Also, the sample is often mostly incomplete regarding the population analyzed. In this context, we have:

$$
\begin{gathered}
\log (\mathrm{sec})_{i, t}=a+b_{1} \log (\text { ecbir })_{i, t}+b_{2} \log (\text { vstoxx })_{i, t}+b_{3} \log (\text { gdp })_{i, t}+b_{4} \log (\text { inf })_{i, t}+b_{5} \log (\text { m3 })_{i, t}+ \\
b_{6} \log (\text { index })_{i, t}+b_{7} \log (\text { ciss })_{i, t}+b_{8}(d v)_{i, t}+\varepsilon_{i, t}
\end{gathered}
$$

With $i=1, \ldots, \mathrm{N}, t=1, \ldots, T$ and $\varepsilon_{i, t}=\alpha_{i}+e_{i, t} \cdot \varepsilon_{i, t}$ is composed by $\alpha_{i}$, certain individual factors that are not taking into account in the model, and $e_{i, t}$, a random perturbation. They are independently and identically distributed: $\alpha_{i} \sim$ i.i.d. $\left(0, \sigma_{\alpha}^{2}\right)$ and $e_{i, t} \sim$ i.i.d. $\left(0, \sigma_{e}^{2}\right)$.

Note that we have three dependent variables (sec, deposit and $n f_{c}$ ). Thereby, we will estimate three different models with the same explanatory variables. But, for simplicity, we only present one empirical specification. Concerning the explanatory variables, we have the ECB policy rate (ecbir) and the Eurostoxx 50 Volatility (vstoxx). In the three equations, we control the estimated values of the dependent variables by real GDP growth and inflation in European Union countries ( $g d p$ and inf), the monetary aggregate $(m 3)$, the Dow Jones Euro Stoxx 50 Price Index (index), the Composite Indicator of Systemic Stress (ciss), and a dummy variable $(d v)$ that captures the restrictive monetary policy adopted by the ECB from December 2005 to August 2008 to prevent inflation. This variable takes 1 in this period and 0 if not.

Moreover, the study is divided into two periods. The first period starts in September 1997 and ends in August 2008: it is the upward phase of the cycle and we call it "good times" in the regression. And the downward phase ("bad times") begins after the Lehman Brothers bankrupt in September 2008, and ends in December 2013. Thereby, the dummy variable is only used in good times.

In a second stage, contrary to equation (1), we suppose that the effects are not random but certain. Thereby, the model perturbation is a classical perturbation $e_{i, t}$. The individual and temporal specificities are represented by the individual and temporal constants that take into account certain unobserved characteristics of the individuals and/or the periods. In this study, we use the fixed effects model assuming that the relationships between the dependent and explanatory variables are the same for all the individuals.

$$
\begin{gathered}
\log (\mathrm{sec})_{i, t}=a+b_{1} \log (\text { ecbir })_{i, t}+b_{2} \log (\text { vstoxx })_{i, t}+b_{3} \log (\text { gdp })_{i, t}+b_{4} \log (\text { inf })_{i, t}+b_{5} \log (m 3)_{i, t}+ \\
b_{6} \log (\text { index })_{i, t}+b_{7} \log (\text { ciss })_{i, t}+b_{8}(d v)_{i, t}+\varepsilon_{i, t}
\end{gathered}
$$

With $e_{i t}$ the standard errors, $i$ the individual and $t$ the time.

In the two specifications, the questions about correlation and heteroscedasticity are considered. Concerning the homoscedasticity assumption, we verify if the variance of the errors of each individual is constant. For each individual $i$, we have to know if $\sigma_{i t}^{2}=\sigma_{i}^{2}$ or $\sigma_{i}^{2}=\sigma^{2}$ for all $i$. According to the Breusch-Pagan test, we have 
heteroscedasticity, and according to the Wald test, we have particularly inter-individual heteroscedasticity. Furthermore, the same variance of the errors for all the individuals indicates that there is intra-individual homoscedasticity. Shortly, our data have the following structure: intra-individual homoscedasticity $\left(\sigma_{i t}^{2}=\sigma_{i}^{2} \forall t\right)$ and inter-individual heteroscedasticity $\left(\sigma_{i}^{2} \neq \sigma^{2} \forall i=1, \ldots, N\right)$.

Then, we investigate correlation of residuals between individuals and residuals autocorrelation problems. Still according to the Breusch-Pagan test, the results suggest that there is no autocorrelation of errors. Thereby, we correct heteroscedasticity and a possible unobserved heterogeneity using cluster corrected standard errors (robust estimation). Then, the choice between fixed and random effect models is made by using the Hausman (1978) test. We have a p-value superior to $5 \%$ in the three estimations. Thereby, random effects models are not biased.

Lastly, to consider endogeneity problem caused by the possible errors in the measures of the variables, dual causality between dependent and explanatory variables and omitted variables bias, we estimate a second group of models with instrumental variables. In this context, we instrument $\log ($ ecbir $)$ by the short term interest rate of ECB $(\log ($ stir $))$, the German interest rate $(\log ($ gir $))$ and spreads between swaps 6-month Euribor and benchmark bonds of 10-year maturity (spread) (the correlations between $\log ($ ecbir) with these variables are $98 \%, 98 \%$ and $80 \%$ respectively). In the case of a two-stage least-squares random-effects model, we use four estimators: G2SLS random-effects estimator (the default) (Balestra \& Varadharajan-Krishnakumar, 1987), Baltagi's EC2SLS estimator (Baltagi, 2008), Baltagi-Chang estimator and an estimation where all the covariates are treated as exogenous and the instrument list ignored (CE). For the fixed effects model, we use two estimators: the fixed-effects (within) regression estimator (the default) and an estimation where all the covariates are treated as exogenous and the instrument list is ignored. According to Pirotte (2011), the comparison of several methods and estimators permits to ensure the validity of certain assumptions retained in the specification of the model.

\section{Results and Conclusions}

The ECB policy rate (ecbir) is relatively low since 1997 (good times). This too low for too long interest rate (November 2005-August 2008) favors an increase in debt securities other than shares to MFI (sec) and loans to Non-Financial Corporations $(n f c)$. According to the values of elasticities, we observe that the impact on sec ( 0.582 and 0.6 in the models with instrumental variables) is higher than that on $n f \mathcal{c}(0.042$ and 0.05 in the models with instrumental variables) (Tables $1 \& 2$ ). First, these results confirm the effectiveness of monetary policy on bank balance sheet. Moreover, they highlight a preference for speculative assets by MFI at the detriment of productive assets. The negative effect of an increase in ecbir on sec and $n f c$ is particularly captured by the dummy variable $(d v)$. All is consistent with the existence of a risk taking channel and the search for yield by banks in good times. On the contrary, an increase in the ECB policy rate positively impacts the deposit facilities by MFI with the ECB (deposit) because of the decrease in the opportunity cost of holding reserves. These empirical results confirm our assumption concerning bank behaviors according to monetary policy in good times. In other words, low interest rates can encourage banks to choose more profitable assets, which is even more accentuated in a context of underestimation of risks. In good times, banks consider market perception and so react in function of the Central bank action. Monetary policy, via its impact on risk aversion, does have an effect on bank balance sheets.

Table 1. Results in good times

\begin{tabular}{|c|c|c|c|c|c|c|}
\hline & $\ln$ (deposit) & & $\ln (\mathrm{sec})$ & & $\ln \left(n f_{c}\right)$ & \\
\hline & $R E$ & $F E$ & $R E$ & $F E$ & $R E$ & $F E$ \\
\hline \multirow{2}{*}{ ln (ecbir) } & $0.307 * * *$ & $0.403 * * *$ & $-0.592 * *$ & $-0.592 * *$ & $-0.042 * * *$ & $-0.042 * * *$ \\
\hline & -9.49 & -5.01 & $(-2.31)$ & $(-2.31)$ & $(-4.76)$ & $(-4.76)$ \\
\hline \multirow{2}{*}{$\ln$ (vstoxx) } & $0.018^{*}$ & $0.063^{*}$ & $-0.821 * * *$ & $-0.821 * * *$ & $-0.026^{* * *}$ & $-0.026^{* * *}$ \\
\hline & -1.85 & -1.94 & $(-4.18)$ & $(-4.18)$ & $(-3.47)$ & $(-3.46)$ \\
\hline \multirow{2}{*}{$g d p$} & $-0.034 * * *$ & $-0.044 * * *$ & $0.002 * *$ & $0.002 * *$ & $0.002 * * *$ & $0.002 * * *$ \\
\hline & $(-8.5)$ & $(-5.2)$ & -2.17 & -2.17 & -6.42 & -6.42 \\
\hline \multirow{2}{*}{$\inf$} & $-0.054 * * *$ & $-0.122 * * *$ & 0.012 & 0.012 & 0.023 & 0.023 \\
\hline & $(-4.48)$ & $(-3.76)$ & -0.29 & -0.31 & -0.92 & -0.92 \\
\hline \multirow{2}{*}{$m 3$} & $-1.631 * * *$ & $-1.55^{* * *}$ & $1.534 * * *$ & $1.534 * * *$ & $1.082 * * *$ & $1.082 * * *$ \\
\hline & $(-57.1)$ & $(-19.69)$ & -3.71 & -3.7 & -4.17 & -4.17 \\
\hline \multirow{2}{*}{ ln (index) } & $-0.819 * * *$ & $-0.878 * * *$ & $0.464 *$ & $0.464 *$ & $0.303 * * *$ & $0.303 * * *$ \\
\hline & $(-51.68)$ & $(-25.19)$ & -1.69 & -1.69 & -3.95 & -3.95 \\
\hline $\ln ($ ciss $)$ & $0.652 * * *$ & $0.64 * * *$ & $-0.023 * * *$ & $-0.023 * * *$ & $-0.016^{* * *}$ & $-0.016 * * *$ \\
\hline
\end{tabular}




\begin{tabular}{lllllll}
\hline & -14.01 & -53.01 & $(-4.02)$ & $(-4.02)$ & $(-2.48)$ & $(-5.79)$ \\
$d v$ & $0.379^{* * *}$ & $0.33^{* * *}$ & $-0.036^{* * *}$ & $-0.036^{* * *}$ & $-0.031^{* * *}$ & $-0.031^{* * *}$ \\
& -27.25 & -9.15 & $(-5.79)$ & $(-6.8)$ & $(-2.53)$ & $(-2.53)$ \\
\multirow{2}{*}{$c s t$} & $2.767^{* * *}$ & $2.59^{* * *}$ & $2.85^{* * *}$ & $2.85^{* * *}$ & $1.848^{* * *}$ & $1.848^{* * *}$ \\
& -57.91 & -18.8 & -9.5 & -10.13 & -7.08 & -8.98 \\
\hline
\end{tabular}

Table 2. Results in good times with instrumental variables

\begin{tabular}{|c|c|c|c|c|c|c|c|c|c|c|c|}
\hline \multirow{13}{*}{$\begin{array}{l}\ln \\
\text { (deposit) }\end{array}$} & & & cst & $d v$ & $\ln ($ ecbir) & $\ln ($ vstoxx $)$ & $g d p$ & inf & $m 3$ & In (index) & $\ln$ (ciss) \\
\hline & & $C I \mathrm{~S}$ & $2.977 * * *$ & $0.396^{* * *}$ & $0.63^{* * *}$ & $0.069^{* * *}$ & $-0.018^{* * *}$ & $-0.057 * * *$ & $-1.605^{* * *}$ & $-0.498 * * *$ & $0.605^{* * *}$ \\
\hline & & & $(6.035)$ & (25.05) & (20.78) & $(4.82)$ & $(-3.58)$ & $(-3.66)$ & $(-56.67)$ & $(-25.58)$ & (14.059) \\
\hline & & Baltagi's & $2.872 * * *$ & $0.395^{* * *}$ & $0.615^{* * *}$ & $0.065^{* * *}$ & $-0.018^{* * *}$ & $-0.057 * * *$ & $-1.607^{* * *}$ & $-0.513^{* * *}$ & $0.607 * * *$ \\
\hline & & $E C 2 S L S$ & $(5.501)$ & (25.68) & (24.56) & (3.5) & $(-3.98)$ & $(-4.4)$ & $(-58.41)$ & $(-21.91)$ & (13.49) \\
\hline & $\pi L$ & Raltatichon & $2.877 * * *$ & $0.396^{* * *}$ & $0.63^{* * * *}$ & $0.069 * * *$ & $-0.018^{* * *}$ & $-0.057 * * *$ & $-1.605^{* * *}$ & $-0.498 * * *$ & $0.605^{* * *}$ \\
\hline & & 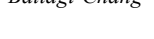 & $(4.896)$ & $(26.82)$ & $(20.45)$ & (4.47) & $(-4.47)$ & $(-4.42)$ & $(-45.98)$ & $(-30.7)$ & (12.041) \\
\hline & & & $2.574 * * *$ & $0.379 * * *$ & $0.607 * * *$ & $0.07^{* * *}$ & $-0.034 * * *$ & $-0.054 * * *$ & $-1.631 * * *$ & $-0.819 * * *$ & $0.652 * * *$ \\
\hline & & $C_{L}$ & $(5.667)$ & $(26.81)$ & $(28.79)$ & $(5)$ & $(-6.2)$ & $(-3.76)$ & $(-54.74)$ & $(-38.33)$ & (11.214) \\
\hline & & $F E$ & $2.696 * * *$ & $0.344 * * *$ & $0.735^{* * *}$ & $0.062 * * *$ & $-0.028 * * *$ & $-0.119^{* * *}$ & $-1.52 * * *$ & $-0.558 * * *$ & $0.592 * * *$ \\
\hline & $E F$ & & (5.89) & (19.09) & (6.99) & (6) & $(-8.88)$ & $(-4.72)$ & $(-16.03)$ & $(-13.11)$ & (15.44) \\
\hline & & $C F$ & $2.595 * * *$ & $0.33 * * *$ & $0.727 * * *$ & $0.063 * * *$ & $-0.044 * * *$ & $-0.123 * * *$ & $-1.55^{* * *}$ & $-0.878 * * *$ & $0.64 * * *$ \\
\hline & & $C_{L}$ & (5.93) & (18.06) & (6.7) & (5.4) & $(-5.59)$ & $(-4.12)$ & $(-19.6)$ & $(-24.42)$ & $(17.28)$ \\
\hline \multirow{13}{*}{$\ln (\mathrm{sec})$} & \multirow{9}{*}{$R E$} & & cst & $d v$ & $\ln ($ ecbir) & $\ln ($ vstoxx) & $g d p$ & inf & $m 3$ & In (index) & $\ln$ (ciss) \\
\hline & & & $3.953 * * *$ & $-0.062 * * *$ & $-0.6^{*}$ & $-0.903 * * *$ & $0.075^{* *}$ & 0.001 & $1.535^{* * *}$ & 0.244 & $-0.515^{* * *}$ \\
\hline & & & $(8.16)$ & $(-6.65)$ & $(-1.83)$ & $(-4.02)$ & $(2.08)$ & $(0.01)$ & $(4.28)$ & $(0.94)$ & $(-4.47)$ \\
\hline & & Baltagi's & $3.955^{* * *}$ & $-0.066 * * *$ & $-0.58^{*}$ & $-0.903 * * *$ & $0.075^{*}$ & 0.001 & $1.535^{* * *}$ & 0.244 & $-0.515^{* * *}$ \\
\hline & & EC2SLS & (10.11) & $(-4.71)$ & $(-1.76)$ & $(-4.96)$ & (1.96) & $(0.01)$ & (3.16) & $(0.96)$ & $(-4.72)$ \\
\hline & & Baltagi-Chang & $3.953 * * *$ & $-0.036 * * *$ & $-0.56^{*}$ & $-0.903 * * *$ & $0.075^{* *}$ & 0.001 & $1.535^{* * *}$ & 0.244 & $-0.515^{* * *}$ \\
\hline & & & $(10.37)$ & $(-5.66)$ & $(-1.76)$ & $(-5.42)$ & $(2.1)$ & $(0.02)$ & (4.39) & $(0.96)$ & $(-4.81)$ \\
\hline & & $C F$ & $2.85^{* * *}$ & $-0.036 * * *$ & $-0.591 * *$ & $-0.821 * * *$ & $0.085^{* * *}$ & 0.006 & $1.534 * * *$ & $0.464^{*}$ & $-0.539 * * *$ \\
\hline & & & $(10.16$ & $(-4.71)$ & $(-2.13)$ & $(-3.47)$ & $(2.22)$ & $(0.11)$ & $(3.33)$ & $(1.81)$ & $(-10.16)$ \\
\hline & \multirow{4}{*}{$F$} & $\Gamma \Gamma$ & $3.954 * * *$ & $-0.036^{* * *}$ & $-0.6^{*}$ & $-0.903 * * *$ & $0.075^{* *}$ & 0 & $1.534 * * *$ & 0.244 & $-0.515^{* * *}$ \\
\hline & & $F E$ & (10.72) & $(-4.73)$ & $(-1.73)$ & $(-4.34)$ & (2.09) & 0 & (4.18) & (1.08) & $(-4.22)$ \\
\hline & & $C \Gamma$ & $2.85^{* * *}$ & $-0.036^{* * *}$ & $-0.592 * * *$ & $-0.821 * * *$ & $0.085^{* * *}$ & 0.006 & $1.534 * * *$ & $0.464^{*}$ & $-0.539 * * *$ \\
\hline & & $C E$ & $(9.07)$ & $(-5.17)$ & $(-2.41)$ & $(-3.73)$ & (2.4) & $(0.13)$ & (3.8) & (4.17) & $(-4.17)$ \\
\hline \multirow{13}{*}{$\ln (n f c)$} & & & cst & $d v$ & $\ln ($ ecbir) & $\ln ($ vstoxx $)$ & $g d p$ & inf & $m 3$ & In (index) & $\ln ($ ciss $)$ \\
\hline & \multirow{8}{*}{$R E$} & $C I S \mathrm{~S}+\mathrm{S}$ & $1.538 * * *$ & $-0.031 * * *$ & $-0.047 * * *$ & $-0.216^{* * *}$ & $0.035^{* * *}$ & 0.012 & $1.077 * * *$ & $0.17^{* * *}$ & $-0.09 * * *$ \\
\hline & & OLD & $(25.1)$ & $(-4.73)$ & $(-5.47)$ & $(-4.13)$ & (5.79) & $(0.44)$ & $(4.71)$ & (2.73) & $(-5.93)$ \\
\hline & & Baltagi's & $1.538^{* * *}$ & $-0.037 * * *$ & $-0.05^{* * *}$ & $-0.216^{* * *}$ & $0.035^{* * *}$ & 0.012 & $1.019^{* * *}$ & $0.17^{* * *}$ & $-0.09^{* * *}$ \\
\hline & & $E C 2 S L S$ & (32.23) & $(-3.54)$ & $(-6.41)$ & $(-4.32)$ & (7.18) & $(0.43)$ & $(4.17)$ & (3.51) & $(-6.65)$ \\
\hline & & Baltaoi_Chano & $1.538^{* * *}$ & $-0.031 * * *$ & $-0.052 * * *$ & $-0.216^{* * *}$ & $0.035^{* * *}$ & 0.012 & $1.077 * * *$ & $0.17^{* * *}$ & $-0.09^{* * *}$ \\
\hline & & & (26.95) & $(-4.93)$ & $(-7)$ & $(-4.14)$ & $(6.35)$ & $(0.41)$ & $(4.08)$ & (2.99) & $(-5.31)$ \\
\hline & & $C F$ & $1.848^{* * *}$ & $-0.031 * * *$ & $-0.05 * * *$ & $-0.165^{* * *}$ & $0.049 * * *$ & 0.014 & $1.077 * * *$ & $0.303 * * *$ & $-0.096^{* * *}$ \\
\hline & & $C E$ & $(21.02)$ & $(-3.15)$ & $(-6.43)$ & $(-4.15)$ & (6.46) & (0.6) & (4.04) & (4.19) & $(-6)$ \\
\hline & \multirow{4}{*}{$F E$} & $\Gamma$ & $1.538 * * *$ & $-0.031 * * *$ & $-0.047 * * *$ & $-0.216^{* * *}$ & $0.035^{* * *}$ & 0.012 & $1.077 * * *$ & $0.17 * * *$ & $-0.09 * * *$ \\
\hline & & & $(25.9)$ & $(-4.41)$ & $(-4.11)$ & $(-3.08)$ & $(5.75)$ & $(0.51)$ & $(4.76)$ & $(2.86)$ & $(-4.84)$ \\
\hline & & $C$ & $1.848^{* * *}$ & $-0.031 * * *$ & $-0.049 * * *$ & $-0.165 * * *$ & $0.049 * * *$ & 0.014 & $1.082 * * *$ & $0.303^{* * *}$ & $-0.096^{* * *}$ \\
\hline & & $C L$ & $(24.08)$ & $(-4.62)$ & $(-4.84)$ & $(-3.45)$ & $(6.63)$ & $(0.52)$ & $(5.61)$ & (3.94) & $(-5.79)$ \\
\hline
\end{tabular}

Secondly, an increase of European VIX ( $v s t o x x$ ) decreases sec and $n f c$, and conversely for a decrease. A low risk aversion implies an increase in the credit agreement (speculative and productive). As in the case of ecbir, the elasticities of $\sec (0.821$ and 0.903 in the models with instrumental variables) are higher than the elasticities of $n f_{c}$ ( 0.026 and 0.216 in the models with instrumental variables). Again, the underestimation of risks in good times encourage banks to choose more risky and profitable assets. Moreover, an increase in vstoxx entails an increase in deposit, and conversely for a decrease. This result implies that a high risk aversion encourages banks 
to seek sources of reliable liquidity. Here, we see that risk is a central element for banks after the crisis.

Table 3. Results in bad times with instrumental variables

\begin{tabular}{|c|c|c|c|c|c|c|c|c|c|c|}
\hline \multirow{13}{*}{$\ln$ (deposit) } & & & $c s t$ & $\ln$ (ecbir) & $\ln$ (vstoxx) & $g d p$ & inf & $m 3$ & $\ln ($ index) & $\ln ($ ciss $)$ \\
\hline & \multirow{8}{*}{$R E$} & \multirow{2}{*}{$G L S$} & $2.56^{* * *}$ & $-1.849 * * *$ & $0.591 * * *$ & $-0.03 * * *$ & $-0.016^{* * *}$ & $-2.04 * * *$ & $-2.11 * * *$ & $1.962 * * *$ \\
\hline & & & $(23.287)$ & $(-67.35)$ & (119.84) & $(-20.35)$ & $(-3.83)$ & $(-4.81)$ & $(-77.07)$ & (85.14) \\
\hline & & Baltagi's & $2.56^{* * *}$ & $-1.851 * * *$ & $0.591 * * *$ & $-0.03 * * *$ & $-0.016 * * *$ & $-2.04 * * *$ & $-2.11 * * *$ & $1.963 * * *$ \\
\hline & & $E C 2 S L S$ & $(17.371)$ & $(-51.95)$ & (96.18) & $(-14.34)$ & $(-3.59)$ & $(-4.92)$ & $(-59.08)$ & (73.52) \\
\hline & & \multirow{2}{*}{ Baltagi-Chang } & $2.56^{* * *}$ & $-1.849 * * *$ & $0.591 * * *$ & $-0.03 * * *$ & $-0.016 * * *$ & $-2 * * *$ & $-2.11 * * *$ & $1.962 * * *$ \\
\hline & & & $(12.268$ & $(-39.31)$ & (104.15 & $(-13.55)$ & $(-3.46)$ & $(-5)$ & $(-40.68)$ & (48.78) \\
\hline & & \multirow{2}{*}{$C E$} & $2.566^{* * *}$ & $-1.308^{* * *}$ & $0.226 * * *$ & $-0.016^{* * *}$ & $-0.04 * * *$ & $-2.02 * * *$ & $-2.351 * * *$ & $1.12 * * *$ \\
\hline & & & $(13.14)$ & $(-39.23)$ & $(23.05)$ & $(-5.82)$ & $(-3.49)$ & $(-4.8)$ & $(-53.34)$ & $(48.11)$ \\
\hline & \multirow{4}{*}{$F E$} & \multirow{2}{*}{$F E$} & $2.563 * * *$ & $-1.83 * * *$ & $0.591 * * *$ & $-0.031 * * *$ & $-0.023 * * *$ & $-2.6 * * *$ & $-2.12 * * *$ & $1.952 * * *$ \\
\hline & & & $(15.245)$ & $(-45.87)$ & (95.39) & $(-15.54)$ & $(-3.77)$ & $(-4.7)$ & $(-50.31)$ & (53.32) \\
\hline & & \multirow{2}{*}{$C E$} & $2.574 * * *$ & $-1.287^{* * *}$ & $0.232 * * *$ & $-0.018 * * *$ & $-0.057 * * *$ & $-2.62 * * *$ & $-2.37 * * *$ & $1.11 * * *$ \\
\hline & & & $(8.064)$ & $(-24.22)$ & $(23.3)$ & $(-4.04)$ & $(-3.41)$ & $(-4)$ & $(-33.34)$ & $(28.92)$ \\
\hline \multirow{9}{*}{$\ln (\mathrm{sec})$} & & & $c s t$ & $\ln (e c b i r)$ & $\ln (v s t o x x)$ & $g d p$ & inf & $m 3$ & In (index) & $\ln ($ ciss $)$ \\
\hline & \multirow{8}{*}{$R E$} & \multirow{2}{*}{$G L S$} & $2.003 * * *$ & 0.123 & $-0.007 * *$ & $0.018^{* * *}$ & $0.073^{* * *}$ & $2.21 * * *$ & $0.003 * * *$ & $-3.05 * *$ \\
\hline & & & $(10.64)$ & $(0.53)$ & $(-2.24)$ & (4.3) & $(4.7)$ & $(3.67)$ & (4.3) & $(-2)$ \\
\hline & & Baltagi's & $2.003 * * *$ & 0.123 & $-0.007 * * *$ & $0.018 * * *$ & $0.073 * * *$ & $2.21 * * *$ & $0.439 * * *$ & $-3.05 * *$ \\
\hline & & $E C 2 S L S$ & $(5.93)$ & $(0.52)$ & $(-2.63)$ & $(4.44)$ & $(4.83)$ & $(3.63)$ & $(4.32)$ & $(-2.01)$ \\
\hline & & \multirow{2}{*}{ Baltagi-Chang } & $2.003 * * *$ & 0.123 & $-0.007 * *$ & $0.018^{* * *}$ & $0.0073 * * *$ & $2.21 * * *$ & $0.003 * * *$ & $-3.05 * *$ \\
\hline & & & (10.59) & $(0.56)$ & $(-2.53)$ & $(4.21)$ & $(4.76)$ & $(3.42)$ & $(4.21)$ & $(2.16)$ \\
\hline & & \multirow{2}{*}{$C E$} & $2.006 * * *$ & 0.078 & $-0.007 * *$ & $0.019^{* * *}$ & $0.072 * * *$ & $2.21 * * *$ & $0.003 * * *$ & $-3 * *$ \\
\hline & & & $(12.75)$ & $(0.86)$ & $(-2.26)$ & $(4.57)$ & $(4.77)$ & $(3.49)$ & $(4.51)$ & $(-2.19)$ \\
\hline \multirow{11}{*}{$\ln \left(n f_{c}\right)$} & \multirow{7}{*}{$R E$} & $G L S$ & $(30.42)$ & (1.39) & $(-2.72)$ & $(0.66)$ & $(1.85)$ & $(0.5)$ & $(0.41)$ & $(-1.89)$ \\
\hline & & Baltagi's & $2.232 * * *$ & 0.039 & $-0.002 * * *$ & 0.002 & $0.023^{*}$ & 1.19 & 0.001 & $-0.54 *$ \\
\hline & & $E C 2 S L S$ & $(25.24)$ & $(1.11)$ & $(-2.93)$ & $(0.56)$ & $(1.85)$ & $(0.43)$ & $(0.43)$ & $(-1.89)$ \\
\hline & & \multirow{2}{*}{ Baltagi-Chang } & $2.232 * * *$ & 0.039 & $-0.002 * * *$ & 0.002 & $0.023 *$ & 1.19 & 0.001 & $-0.54 *$ \\
\hline & & & $(25.21)$ & $(1.46)$ & $(-2.58)$ & $(0.54)$ & (1.93) & $(0.56)$ & $(0.44)$ & $(-1.79)$ \\
\hline & & \multirow{2}{*}{$C E$} & $2.231 * * *$ & 0.025 & $-0.002 * * *$ & 0.002 & $0.022 *$ & 1.22 & 0.001 & $-0.582^{*}$ \\
\hline & & & $(28.76)$ & $(1.51)$ & $(-2.84)$ & $(0.51)$ & (1.99) & $(0.66)$ & $(0.27)$ & $(-1.85)$ \\
\hline & \multirow{4}{*}{$F E$} & \multirow{2}{*}{$F E$} & $2.232 * * *$ & 0.039 & $-0.002 * * *$ & 0.002 & $0.023^{*}$ & 1.2 & 0.001 & $-0.54 *$ \\
\hline & & & (21.69) & (1.34) & $(-2.69)$ & $(0.46)$ & $(1.85)$ & $(0.64)$ & $(0.4)$ & $(-1.86)$ \\
\hline & & \multirow{2}{*}{$C E$} & $2.231 * * *$ & 0.024 & $-0.002 * * *$ & 0.002 & $0.022 *$ & 1.23 & 0.001 & $-0.582 *$ \\
\hline & & & (21.63) & $(1.2)$ & $(-2.74)$ & $(0.65)$ & (1.96) & $(0.56)$ & $(0.28)$ & (1.77) \\
\hline
\end{tabular}

Concerning the control variables, we observe that the bank portfolio choices are made in a cyclical way. In fact, there is a positive relation between $g d p$, inf, $m 3$ and index with $s e c$ and $n f c$ (and negative with deposit) because these variables are indicative of a good economic conjuncture. "Productive" and "speculative" assets are procyclical and "safe" assets countercyclical. In the case of stress indicator (ciss), we have the inverse results; a negative relation with $s e c$ and $n f c$, and a positive relation with deposit. Indeed, in good times, this indicator of financial stability is at the lowest; promoting a preference for risk.

After the crisis, the results described above (Tables 1-4) tend to indicate that the expensive monetary policy adopted by the ECB after the crisis does not impact $s e c$ and $n f c$. This can partially be explained by the importance of the high risk aversion of MFI. In fact, liquidity and counterparty risks are so important, that monetary policy does not manage to influence bank choices. Indeed, vstoxx significantly impacts the three 
explanatory variables. The higher risk aversion discourages banks to choose $s e c$ and $n f c$ (with a superior effect on $s e c$ ) and encourages them to prefer liquidity (positive sign with deposit). The higher elasticity of the variable sec witnesses a more procyclical characteristic of risky assets. In brief, risk aversion plays a role in determining bank choices along the cycle (in good times, via its reaction to monetary policy impact). In bad times, the interest rate policy looses its power on bank decisions, which can be explained in part by the central role of risk aversion.

Table 4. Results in bad times

\begin{tabular}{|c|c|c|c|c|c|c|}
\hline & $\ln$ (deposit) & & $\ln (\mathrm{sec})$ & & $\ln \left(n f_{c}\right)$ & \\
\hline & $R E$ & $F E$ & $R E$ & $F E$ & $R E$ & $F E$ \\
\hline \multirow{2}{*}{$\ln ($ ecbir) } & $-1.303 * * *$ & $-1.279 * * *$ & 0.078 & 0.079 & 0.024 & 0.024 \\
\hline & $(-38.6)$ & $(-24.27)$ & -0.98 & -0.97 & -1.6 & -1.64 \\
\hline \multirow{2}{*}{$\ln$ (vstoxx) } & $0.233 * * *$ & $0.242 * * *$ & $-0.007 * * *$ & $-0.007 * * *$ & $-0.002 *$ & $-0.002 *$ \\
\hline & $(15.31)$ & (11.86) & $(-3.13)$ & $(-3.13)$ & $(-1.8)$ & $(-1.86)$ \\
\hline \multirow{2}{*}{$g d p$} & $-0.016 * * *$ & $-0.018 * * *$ & $0.019 * * *$ & $0.019 * * *$ & 0.002 & 0.002 \\
\hline & $(-5.46)$ & $(-3.88)$ & $(3.47)$ & $(3.47)$ & $(0.6)$ & $(0.6)$ \\
\hline \multirow{2}{*}{ inf } & $-0.044 * *$ & $-0.064 *$ & $0.072 * * *$ & $0.072 * * *$ & $0.022 *$ & $0.022 *$ \\
\hline & $(-2.03)$ & $(-1.91)$ & $(6.56)$ & $(6.56)$ & $(1.75)$ & $(1.75)$ \\
\hline \multirow{2}{*}{$m 3$} & $-2.251 * *$ & $-2.346 * * *$ & $2.21 * *$ & $2.21 * *$ & 2.339 & 2.233 \\
\hline & $(-2.74)$ & $(-2.81)$ & $(2.52)$ & (2.52) & $(0.55)$ & $(0.55)$ \\
\hline \multirow{2}{*}{ In (index) } & $-2.341 * * *$ & $-2.357 * * *$ & $0.003 * * *$ & $0.003 * * *$ & 0.001 & 0.002 \\
\hline & $(-52.32)$ & $(-34.14)$ & (7.09) & $(7.08)$ & $(0.3)$ & $(0.3)$ \\
\hline \multirow{2}{*}{$\ln ($ ciss $)$} & $1.115^{* * *}$ & $1.103 * * *$ & $-2.858 * * *$ & $-2.858 * * *$ & $-0.582 *$ & $-0.582 *$ \\
\hline & $(43.41)$ & $(27.21)$ & $(-5.29)$ & $(-5.28)$ & $(-1.86)$ & $(-1.86)$ \\
\hline \multirow{2}{*}{$c s t$} & $2.728 * * *$ & $2.798 * * *$ & $3.058 * * *$ & $3.057 * * *$ & $2.331 * * *$ & $2.231 * * *$ \\
\hline & $(12.37)$ & (10.14) & (20.69) & (9.656) & $(8.42)$ & $(7.062)$ \\
\hline
\end{tabular}

In conclusion, our study has several results. First, it confirms a preference for speculative assets from MFI in European countries before the 2007-2008 crisis and a flight to liquidity afterwards. The second result concerns the determinants of this credit allocation. Bank choices are largely influenced by monetary policy in the upward phase. Before the crisis, via the impact on risk aversion, changes in policy rates modified risk perceptions, encouraging a preference by banks for more risky assets. This strategy answers also to a search for yield. After the crisis, traditional monetary policy becomes no effective because of a change in rationality of banks and the important role of high risk aversion. The fact that the official interest rate has no impact on productive loans after the crisis justifies the use of unconventional measures taken by ECB. Indeed, the fear of liquidity risk is so high that we could understand that measures to provide liquidity could limit the credit rationing by reducing risk aversion. So the following question concerns the effectiveness of unconventional measures to encourage credit distribution. To be effective, monetary policy has to produce a beneficial effect on risk aversion. According to $\mathrm{Wu}$ (2008), it could be counterproductive and accentuate tensions on financial markets. An extension of this study would be to analyze the effect of such measures on credit allocation, which could highlight the importance of a signal effect of monetary policy during bad times.

\section{References}

Adrian, T., \& Estrella, A. (2010). Financial intermediaries and monetary economics. Staff Report, Federal Reserve Bank of New York. http://dx.doi.org/10.1016/b978-0-444-53238-1.00012-0

Allen, F., Carletti, E., \& Gale, D. (2009). Interbank market liquidity and central bank intervention. Journal of Monetary Economics, 56(5), 639-652. http://dx.doi.org/10.1016/j.jmoneco.2009.04.003

Altunbas, Y., Gambacorta, L., \& Marqués-Ibáñez, D. (2010). Does monetary policy affect bank risk-taking? Bank for International Settlements Working Papers, March 298.

Andritzky, J., Jobst, A., Nowak, S. B., Ait-Sahalia, Y., \& Tamirisa, N. (2009). How to Stop a Herd of Running Bears? Market Response to Policy Initiatives During the Global Financial Crisis. IMF Working Papers, $1-48$.

Angelini, P., Nobili, A., \& Picillo, C. (2011). The interbank market after August 2007: What has changed, and why? Journal of Money, Credit and Banking, 43(5), 923-958. 
http://dx.doi.org/10.1111/j.1538-4616.2011.00402.x

Balestra, P., \& Krishnakumar, J. (1987). Full information estimations of a system of simultaneous equations with error component structure. Econometric Theory, 3, 223-246. http://dx.doi.org/10.1017/S0266466600010318

Baltagi, B. H. (2008). Econometric Analysis of Panel Data (4th ed.). Chichester: Wiley.

Battagi, B. H., \& Chang, Y. J. (1994). Incomplete panels: A comparative study of alternative estimators for the unbalanced one-way error component regression model. Journal of Econometrics, 62, 67-89. http://dx.doi.org/10.1016/0304-4076(94)90017-5

Berger, A. N., \& Udell, G. F. (2004). The institutional memory hypothesis and the procyclicality of bank lending behavior. Journal of Financial Intermediation, 13(4), 458-495. http://dx.doi.org/10.1016/j.jfi.2004.06.006

Bernanke, B., Gertler, M., \& Gilchrist, S. (1994). The financial accelerator and the flight to quality. National Bureau of Economic Research Working Paper, July 4789, 1994.

Bernanke, B., Reinhart, V., \& Sack, B. (2004). Monetary policy alternatives at the zero bound: An empirical assessment. Brookings Papers on Economic Activity, 2, 1-100. http://dx.doi.org/10.1353/eca.2005.0002

Borio, C., \& Drehmann, M. (2011). Toward an Operational Framework for Financial Stability: "Fuzzy" Measurement and Its Consequences. Central Banking, Analysis, and Economic Policies Book Series 15: 63-123.

Borio, C., \& Zhu, H. (2012). Capital regulation, risk-taking and monetary policy: A missing link in the transmission mechanism? Journal of Financial Stability, 8(4), $236-251$. http://dx.doi.org/10.1016/j.jfs.2011.12.003

Breusch, T. S., \& Pagan, A. R. (1980). The Lagrange multiplier test and its applications to model specification in econometrics. Review of Economic Studies, 47, 239-253. http://dx.doi.org/10.2307/2297111

Brissimis, S. N., \& Delis, M. D. (2010). Bank heterogeneity and monetary policy transmission. Bank of Greece Working Paper, August 101, 2010.

Caballero, R. J., \& Krishnamurthy, A. (2008). Collective risk management in a flight to quality episode. The Journal of Finance, 63(5), 2195-2230. http://dx.doi.org/10.1111/j.1540-6261.2008.01394.x

Calza, A. M., \& Sousa, J. (2006). Credit in the euro area: An empirical investigation using aggregate data. The Quarterly Review of Economics and Finance, 46(2), 211-226. http://dx.doi.org/10.1016/j.qref.2005.02.001

Cardone-Riportella, C., Samaniego-Medina, R., \& Trujillo-Ponce, A. (2010). What drives bank securitisation? The Spanish experience. Journal of Banking \& Finance, 34(11), 2639-2651. http://dx.doi.org/10.1016/j.jbankfin.2010.05.003

Delis, M. D., \& Kouretas, G. P. (2011). Interest rates and bank risk-taking. Journal of Banking \& Finance, 35(4), 840-855. http://dx.doi.org/10.1016/j.jbankfin.2010.09.032

Duffie, D. (2008). Innovations in credit risk transfer: Implications for financial stability. Bank for International Settlements, Monetary and Economic Department, July 2007. http://dx.doi.org/10.2139/ssrn.1165484

Freixas, X., \& Jorge, J. (2008). The role of interbank markets in monetary policy: A model with rationing. Journal of Money, Credit and Banking, 40(6), 1151-1176. http://dx.doi.org/10.1111/j.1538-4616.2008.00152.x

Gai, P., \& Vause, N. (2004). Risk appetite: Concept and measurement. Financial Stability Review, 17, 127-136.

Gambacorta, L. (2009). Monetary policy and the risk-taking channel. BIS Quarterly Review, 43-53.

Gambacorta, L., \& Marques-Ibanez, D. (2011). The bank lending channel: Lessons from the crisis. Economic Policy, 26(66), 135-182. http://dx.doi.org/10.1111/j.1468-0327.2011.00261.x

Gauthier, C., \& Tomura, H. (2011). Comprendre et mesurer le risque de liquidité: Une sélection d'études récentes. Revue de la Banque du Canada, Printemps, 3-12.

Gavin, M., \& Hausmann, R. (1996). The roots of banking crises: the macroeconomic context. Banking Crises in Latin America, 27-63. http://dx.doi.org/10.2139/ssrn.1815948

Gilles, P. H., Gauvin, M. S., \& Huchet, N. (2013). Banking Sector and Monetary Policy Transmission: Bank capital, Credit and Risk Taking Channels. Modern Economy Journal, 4(1), 77-86. http://dx.doi.org/10.4236/me.2013.41010

Hausman, J. A. (1978). Specification Tests in Econometrics. Econometrica, 46(6), 1251-1271. 
http://dx.doi.org/10.2307/1913827

Ioannidou, V. P., Ongena, S., \& Peydró-Alcalde, J. L. (2008). Monetary policy, risk-taking, and pricing: Evidence from a quasi-natural experiment. Tilburg University.

Jimenez, G., Ongena, S., Peydró, J. L., \& Saurina, J. (2014). Hazardous Times for Monetary Policy: What Do Twenty-Three Million Bank Loans Say About the Effects of Monetary Policy on Credit Risk-Taking? Econometrica, 82(2), 463-505. http://dx.doi.org/10.3982/ECTA10104

Juglar, C. (1862). Des Crises Commerciales et de leur retour périodique en France, an Angleterre et aux États-Unis. Paris: Guillaumin, Alcan (reprinted New York: Kelly, 1967), Paris.

Maddaloni, A., \& Peydró, J. L. (2011). Bank risk-taking, securitization, supervision, and low interest rates: Evidence from the Euro-area and the US lending standards. Review of Financial Studies, 24(6), 2121-2165. http://dx.doi.org/10.1093/rfs/hhr015

Nijskens, R., \& Wagner, W. (2011). Credit risk transfer activities and systemic risk: How banks became less risky individually but posed greater risks to the financial system at the same time. Journal of Banking \& Finance, 35(6), 1391-1398. http://dx.doi.org/10.1016/j.jbankfin.2010.10.001

Pepin, D. (2014). Instabilité des comportements et cycles financiers: Une relecture dans un cadre rationnel avec préférences endogènes. Consulté le juin 13.

Pirotte, A. (2011). Econométrie des données de panel: Théorie et applications, Economica.

Rajan, R. G. (2006). Has finance made the world riskier? European Financial Management, 12(4), 499-533. http://dx.doi.org/10.1111/j.1468-036X.2006.00330.x

Rossi, C., \& Gambacorta, L. (2007). Modeling Bank Lending in the Euro Area: A Non-Linear Approach. Bank of Italy Temi di Discussione (Working Paper), November 650. http://dx.doi.org/10.2139/ssrn.1075262

Smith, D. R., \& Whitelaw, R. F. (2009). Time-varying risk aversion and the risk-return relation. NYU Stern School of Business Working Paper. http://dx.doi.org/10.2139/ssrn.1663542

Sorensen, K. C., Marques-Ibanez, D., \& Rossi, C. (2012). Modelling loans to non-financial corporations in the euro area. Bank of Italy Temi di Discussione (Working Paper), February 857, 2012. http://dx.doi.org/10.2139/ssrn.2030839

Wald, A. (1943). Tests of statistical hypotheses concerning several parameters when the number of observations is large. Transactions of the American Mathematical Society, 54, 426-482. http://dx.doi.org/10.1090/S0002-9947-1943-0012401-3

$\mathrm{Wu}, \mathrm{T}$. (2008). On the effectiveness of the Federal Reserve's new liquidity facilities. Federal Reserve Bank of Dallas Working Paper, May 0808, 2008. http://dx.doi.org/10.2139/ssrn.1136942

\section{Notes}

Note 1 . Note that underestimation of risks can be accentuated by their methods of valuation and especially since banks use securitization (Duffie, 2008; Gauthier \& Tomura, 2011; Nijskens \& Wagner, 2011). Moreover, rating agencies, on which the estimates are based, would give their note "through the cycle" (Borio \& Drehmann, 2011).

Note 2. Austria, Belgium, Finland, France, Germany, Greece, Ireland, Italy, Luxembourg, Netherlands, Spain, Portugal and United Kingdom.

Note 3. The Key ECB interest rate-Marginal lending facility-is expressed in Change in percentage points compared to previous rate.

Note 4. The CBOE Volatility Index, introduced in 1993, is a measure of market expectations of near-term volatility conveyed by S\&P 500 stock index option prices.

Note 5. Inflation concern consumer prices and is expressed in annual rate of change.

Note 6. M3 is considered as Broad money and comprises, according to the ECB's definition, "M2 and marketable instruments issued by the MFI sector. Certain money market instruments, in particular money market fund (MMF) shares/units and repurchase agreements are included in this aggregate. A high degree of liquidity and price certainty make these instruments close substitutes for deposits. As a result of their inclusion, M3 is less affected by substitution between various liquid asset categories than narrower definitions of money, and is 
therefore more stable.” This definition justifies the choice of M3 as control variable and not M1.

\section{Copyrights}

Copyright for this article is retained by the author(s), with first publication rights granted to the journal.

This is an open-access article distributed under the terms and conditions of the Creative Commons Attribution license (http://creativecommons.org/licenses/by/3.0/). 